\title{
$577 \mathrm{~nm}$ 레이저 섬유주성형술의 단기 임상효과 \\ Short-Term Clinical Outcomes of Laser Trabeculoplasty Using a 577-nm Wavelength Laser
}

\author{
김종민 · 조경진 · 경성은 · 장무환 \\ Jong Min Kim, MD, Kyong Jin Cho, MD, Sung Eun Kyung, MD, PhD, Moo Hwan Chang, MD, PhD \\ 단국대학교 의과대학 안과학교실 \\ Department of Ophthalmology, Dankook University Medical College, Cheonan, Korea
}

\begin{abstract}
Purpose: To evaluate the pressure-lowering effects of single-spot laser trabeculoplasty and patterned laser trabeculoplasty using a $577-\mathrm{nm}$ wavelength laser.

Methods: A total 35 eyes of 35 patients with primary open-angle glaucoma were enrolled in this study. Eighteen eyes of 18 patients were treated with $360^{\circ}$ single-spot laser trabeculoplasty and 17 eyes of 17 patients were treated with $360^{\circ}$ patterned laser trabeculoplasty. All patients were evaluated after laser trabeculoplasty at 1 week, 1 month, 3 months, and 6 months using slit lamp examination and Goldmann applanation tonometry.

Results: At 6 months postoperatively, the single-spot laser trabeculoplasty group had a mean IOP of $15.89 \pm 3.89 \mathrm{~mm} \mathrm{Hg}$ with a mean IOP reduction of $37.1 \%$, while the patterned laser trabeculoplasty group had a mean IOP of $17.57 \pm 2.64 \mathrm{~mm} \mathrm{Hg}$ with a mean IOP reduction of $27.1 \%$.

Conclusions: Laser trabeculoplasty with a 577-nm optically pumped semiconductor laser was safe and demonstrated an IOP lowering effect. There were no significant differences in the IOP lowering effects between the single-spot laser trabeculoplasty and the patterned laser trabeculoplasty.
\end{abstract}

J Korean Ophthalmol Soc 2014;55(4):563-569

Key Words: Laser trabeculoplasty, PASCAL, Pattern laser trabeculoplasty

원발개방각녹내장은 특징적인 녹내장성 시신경 손상과 시야결손, 전방각은 개방되어 있으며 안압상승의 원인이 될만한 뚜렷한 안과적 혹은 전신적 이상이 없는 상태를 말 한다. 일반적인 경우 치료 전 안압에서 $20-30 \%$ 정도의 안

- Received: 2013. 7. 8.

- Accepted: 2014. 2. 20.

- Address reprint requests to Moo Hwan Chang, MD, PhD Department of Ophthalmology, Dankook University Hospital, \#201 Manghyang-ro, Dongnam-gu, Cheonan 330-715, Korea Tel: 82-41-550-6497, Fax: 82-41-561-0137

E-mail: changmh@dankook.ac.kr

* This study was presented as a e-poster at the 109th Annual Meeting of the Korean Ophthalmological Society 2013.
압감소를 목표로 하며 약물치료, 레이저섬유주성형술 및 수술적 방법이 사용되고 있다. 점안안압하강제에 반응하지 않거나 안압하강제 사용의 순응도가 좋지 않은 원발개방각 녹내장 환자의 치료에 레이저섬유주성형술이 고려될 수 있 다. 1979년 Wise and Witter ${ }^{1}$ 가 처음으로 레이저섬유주성형 술의 프로토콜을 기술한 이후 아르곤레이저섬유주성형술이 시행되어졌다. 하지만 섬유주 비색소세포 및 섬유주 기질에 도 변형을 일으키는 단점이 존재하여 반복적인 시술이 어려 웠다. 1995년 Latina and Park에 의해 섬유주 색소세포만 선 택적으로 흡수되는 $532 \mathrm{~nm}$ Q-switched frequency-doubled $\mathrm{Nd}$ :YAG laser를 이용한 선택적레이저섬유주성형술이 보고 된 후 반복적인 시술이 가능해져 널리 사용되고 있다.

최근 소개된 새로운 레이저 치료방식인 패턴 스캐닝 레 
이저(PASCAL)는 망막에 한번에 많은 레이저 광응고반을 만들어내어 망막질환 치료에 사용되고 있다. ${ }^{3}$ 또한 패턴 레 이저섬유주성형술 기능이 있어 녹내장 환자의 치료에도 사 용되고 있다. Turati et $\mathrm{al}^{4}$ 은 개방각 녹내장환자 25명 47안을 대상으로 $532 \mathrm{~nm}$ 파장의 레이저를 이용한 패턴 레이저섬유 주성형술을 시행후 6 개월 경과관찰에서 $24 \%$ 의 안압하강 효 과를 보고하였다. PASCAL Streamline $577^{\mathrm{TM}}$ (Optimedia, Santa Clara, CA, USA)기종은 $577 \mathrm{~nm}$ 파장의 optically pumped semiconductor laser를 사용하며 패턴 레이저섬유 주성형술시 한번에 $11.25^{\circ}$ 의 섬유주에 레이저를 조사하여 32 회의 조사로 $360^{\circ}$ 섬유주에 레이저를 조사할 수 있다. 또 한 아직까지 국내문헌에 패턴 레이저섬유주성형술의 효과 및 $577 \mathrm{~nm}$ 파장의 레이저를 이용한 레이저섬유주성형술의 결과가 보고된 바 없다. 저자들은 원발개방각녹내장 환자 를 대상으로 $577 \mathrm{~nm}$ 파장의 레이저를 이용한 $360^{\circ}$ 패턴 레 이저섬유주성형술 및 $360^{\circ}$ 단일 광응고반 레이저섬유주성 형술의 효과를 알아보고자 하였다.

\section{대상과 방법}

2012년 1월부터 2012년 7월까지 원발개방각녹내장으로 $360^{\circ}$ 단일 광응고반 레이저섬유주성형술과 $360^{\circ}$ 패턴 레이 저섬유주성형술(Patterned Laser Trabeculoplasty)을 시행 받 은 환자 35 명을 대상으로 전향적인 연구를 시행하였다. 원 발개방각녹내장은 골드만 압평안압계로 3 회 이상 측정한 안압이 $21 \mathrm{mmHg}$ 이상, 험프리 24-2 시야검사에서 녹내장 의 특징적인 변화가 관찰, 전방각경검사상 전방각이 개방, 시신경 유두함몰비가 0.6 이상으로 정의하였다. 골드만 압 평안압계로 측정한 안압이 $21 \mathrm{mmHg}$ 이상 또는 기저안압 으로부터 $20 \%$ 이상 감소하지 못하였을 경우를 안압상승기

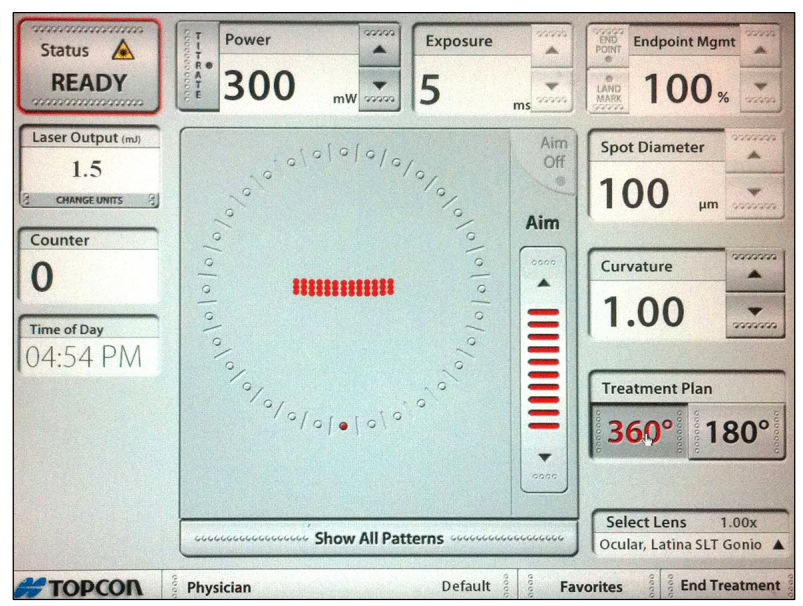

Figure 1. Graphic user interface for patterned laser trabeculoplasty software.
간으로 정의하였고, 녹내장성 시야손상의 정도는 HodappParrish-Anderson criteria에 따라 분류하였다. ${ }^{5}$ 안압조절을 위해 사용하는 약물 개수에 상관없이 레이저섬유주성형술 을 통해 최소한의 약물사용을 원하는 환자를 대상으로 하 였으며, 무작위 방법으로 단일 광응고반 레이저섬유주성형
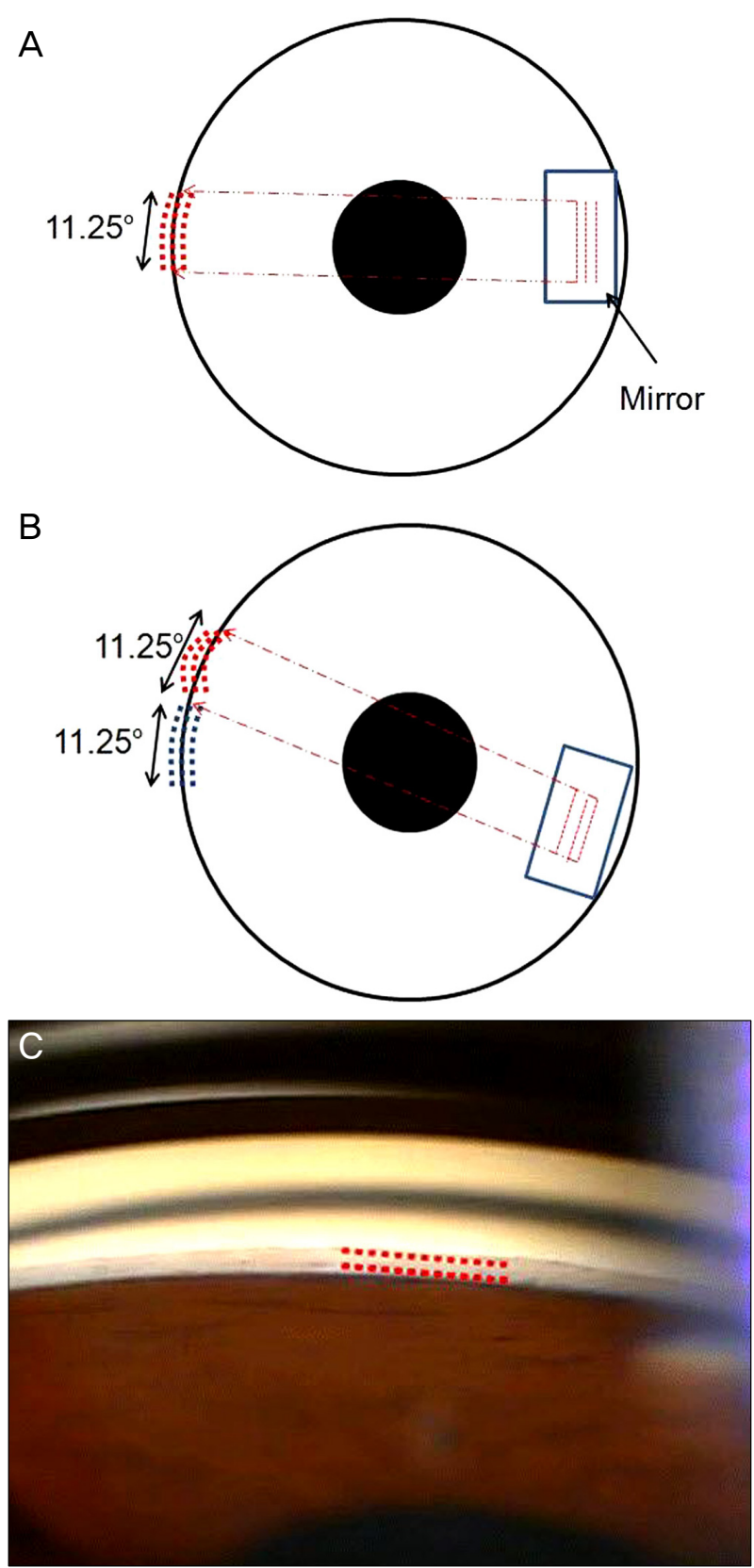

Figure 2. Procedure of patterned laser trabeculoplasty. (A) Schematic view of patterned laser trabeculoplasty. Pattern of Aiming beam $(635 \mathrm{~nm})$ is projected on trabecular meshwork. Once a physician presses the foot pedal, PASCAL photocoagulator delivers a patterned laser on trabecular meshwork. (B) After shooting the laser, the pattern is automatically rotated clockwise by $11.25^{\circ}$. (C) Gonioscopic view of patterned laser trabeculoplasty. 
술과 패턴 레이저섬유주성형술 2 개의 군으로 분류하였다. 이전에 레이저치료 및 안수술의 병력이 있거나 안내염증이 심한 경우는 대상에서 제외하였다.

단일 광응고반 레이저섬유주성형술을 시행하는 경우 대 상안을 점안 마취후 Latina SLT 렌즈(Ocular instruments, $\mathrm{USA}$ )를 각막 위에 위치시키고 레이저 출력 $300 \mathrm{~mW}$, 크기 는 $200 \mu \mathrm{m}$, 조사시간 $20 \mathrm{~ms}, 577 \mathrm{~nm}$ 파장의 레이저를 방출 하는 optically-pumped semiconductor laser를 이용하여 섬 유주의 $360^{\circ}$ 에 평균 100 회의 레이저를 조사하였다.

패턴 레이저섬유주성형술은 터치스크린에서 레이저 출 력, 조사범위를 시술자가 선택할 수 있다(Fig. 1). 하나의 패 턴에 39 개의 광응고반이 섬유주의 $11.25^{\circ}$ 범위를 조사하며 1 회의 패턴 후에는 자동적으로 $11.25^{\circ}$ 시계방향으로 회전 하여 다음 조사를 준비한다(Fig. 2) 본 연구에서는 레이저 출력 $300 \mathrm{~mW}$, 크기는 $100 \mu \mathrm{m}$, 조사시간 $5 \mathrm{~ms}$, curvature 1.00 의 레이저를 섬유주의 $360^{\circ}$ 에 평균 1252 회의 레이저를 조사하였다. 시술 후에는 사용 중이던 점안 안압하강제를 유지하며, $0.1 \%$ fluorometholone을 1주간 하루 4회 점안하 도록 하였다. 레이저 시술 1 시간 후, 1 주, 1 개월, 3 개월, 6 개 월에 안압을 측정하였다. 시술 후 1 주에 세극등현미경검사 로 전방내 염증여부를 검사하였고, 6개월에 전방각경으로
주변홍채유착 여부를 관찰하였다.

통계적 분석방법은 SPSS 18.0에서 Mann-Whitney test, Wilcoxon signed ranks test, Chi-square test, Kaplan-Meier survival analysis를 사용하였다.

\section{결 과}

단일 광응고반 레이저섬유주성형술를 시행 받았던 환자 군의 평균 나이는 53 세로 남자는 10 명(10안), 여자는 8 명(8 안)이었고, 술전 안압하강제의 사용개수는 평균 $0.81 \pm 1.1$ 개였다. 패턴 레이저섬유주성형술을 시행 받은 환자군의 평균 나이는 46세로 남자 8명(8안), 여자 9명(9안)이었고, 술전 안압하강제의 사용개수는 평균 $1.3 \pm 1.2$ 개였다. 두 군의 환자들의 평균연령, 성별, 시술 전 사용한 점안액 개 수, 시술 전 안압, 안압상승기간, 녹내장성 시야손상 정도 는 통계학적으로 유의한 차이가 없었다(Table 1). 단일 광 응고반 레이저섬유주성형술을 시행 받은 환자군의 술전 평균 안압은 $25.27 \pm 7.51 \mathrm{mmHg}$ 였으며, 1주일 후 $18.09 \pm$ $4.44 \mathrm{mmHg}$ (28.5\% 안압감소), 1개월 후 $19.44 \pm 5.15 \mathrm{mmHg}$ (23.1\% 안압감소), 3 개월 후 $17.67 \pm 5.13 \mathrm{mmHg}$ (30.1\% 안 압감소), 6개월 후 $15.89 \pm 3.89 \mathrm{mmHg}(37.1 \%$ 안압감소)로

Table 1. Patient demographics

\begin{tabular}{lccc}
\hline & Single spot laser group & Patterned laser group & $p$-value \\
\hline Age (years) & $53 \pm 16.59(19-72)$ & $46 \pm 9.5(35-65)$ & $0.30^{*}$ \\
Sex : & & 8 & $0.87^{\dagger}$ \\
$\quad$ Male & 10 & 9 & \\
$\quad$ Female & 8 & $1.30 \pm 1.25(0-3)$ & $0.44^{*}$ \\
Mean number of glaucoma medication (n, range) & $0.81 \pm 1.17(0-3)$ & $24.11 \pm 4.17(19-45)$ & $0.91^{*}$ \\
Baseline IOP (mm Hg, range) & $25.27 \pm 7.51(18-32)$ & $2.35 \pm 1.59(1-6)$ & $0.64^{*}$ \\
Mean duration of increased IOP (month) & $2.44 \pm 1.69(1-5)$ & 8 & $0.49^{\dagger}$ \\
Degrees of glaucomatous visual field loss (month, range) & & 5 & 6 \\
$\quad$ Early defect & 7 & & \\
$\quad$ Moderate defect & 5 & & \\
$\quad$ Severe defect & 4 & & \\
\hline
\end{tabular}

Values are presented as mean \pm SD.

IOP $=$ intraocular pressure .

${ }^{*}$ Mann-Whitney $U$-test; ${ }^{\dagger}$ Chi-square test.

Table 2. Changes of mean intraocular pressure during 6 months of follow-up

\begin{tabular}{|c|c|c|c|c|c|c|}
\hline \multirow{2}{*}{ Time } & \multicolumn{3}{|c|}{ Single spot laser group } & \multicolumn{3}{|c|}{ Patterned laser group } \\
\hline & Number of eyes & IOP $(\mathrm{mm} \mathrm{Hg})$ & $p$-value ${ }^{*}$ & Number of eyes & IOP $(\mathrm{mm} \mathrm{Hg})$ & $p$-value \\
\hline Baseline & 18 & $25.27 \pm 7.51(18-32)$ & & 17 & $24.11 \pm 4.17(19-45)$ & \\
\hline 1 week & 18 & $18.09 \pm 4.44(12-25)$ & 0.01 & 17 & $17.78 \pm 2.49(14-21)$ & 0.01 \\
\hline 1 month & 16 & $19.44 \pm 5.15(10-26)$ & 0.02 & 15 & $19.44 \pm 5.15(12-20)$ & 0.03 \\
\hline 3 months & 16 & $17.67 \pm 5.13(11-23)$ & 0.02 & 15 & $18.43 \pm 1.40(17-20)$ & 0.02 \\
\hline 6 months & 18 & $15.89 \pm 3.89(11-21)$ & 0.01 & 17 & $17.57 \pm 2.64(15-22)$ & 0.03 \\
\hline
\end{tabular}

Values are presented as mean \pm SD.

*Wilcoxon signed ranks test. 
Table 3. Success rate of laser trabeculoplasty

\begin{tabular}{lcrr}
\hline & \multirow{2}{*}{ Success } & \multicolumn{2}{c}{ Failure } \\
\cline { 3 - 4 } & & IOP decreased & IOP increased \\
\hline Single spot laser trabeculoplasty & $50 \%(9)$ & $44.44 \%(8)$ & $5.56 \%(1)$ \\
Patterned laser trabeculoplasty & $52.94 \%(9)$ & $47.06 \%(8)$ & $0 \%(0)$ \\
$p$-value & 0.87 & & \\
\hline
\end{tabular}

IOP $=$ intraocular pressure.

"Chi-square test.

Table 4. Mean IOP reduction of subgroups between single spot laser trabeculoplasty and patterned laser trabeculoplasty groups using success definitions

\begin{tabular}{llccc}
\hline & & Baseline IOP $(\mathrm{mm} \mathrm{Hg})$ & IOP after $6 \mathrm{months}(\mathrm{mm} \mathrm{Hg})$ & $p$-value \\
\hline SLT & Success subgroup $(\mathrm{n}=9)$ & $27.40 \pm 10.08(19-45)$ & $14.50 \pm 2.88(11-18)$ & 0.01 \\
& Failure subgroup $(\mathrm{n}=9)$ & $23.50 \pm 3.45(19-29)$ & $17.00 \pm 4.16(11-21)$ & 0.42 \\
& $p$-value $^{\dagger}$ & 0.03 & 0.16 & 0.01 \\
PLT & Success subgroup $(\mathrm{n}=9)^{\text {Failure subgroup }(\mathrm{n}=8)}$ & $26.80 \pm 3.27(24-32)$ & $17.50 \pm 2.08(15-20)$ & 0.06 \\
& $p$-value & $20.75 \pm 2.22(18-23)$ & $17.67 \pm 3.79(15-22)$ & 0.30 \\
\hline
\end{tabular}

Values are presented as mean $\pm \mathrm{SD}$.

IOP = intraocular pressure; SLT = single spot laser trabeculoplasty; PLT = patterned laser trabeculoplasty.

${ }^{*}$ Wilcoxon signed ranks test; ${ }^{\dagger}$ Mann-Whitney $U$-test.

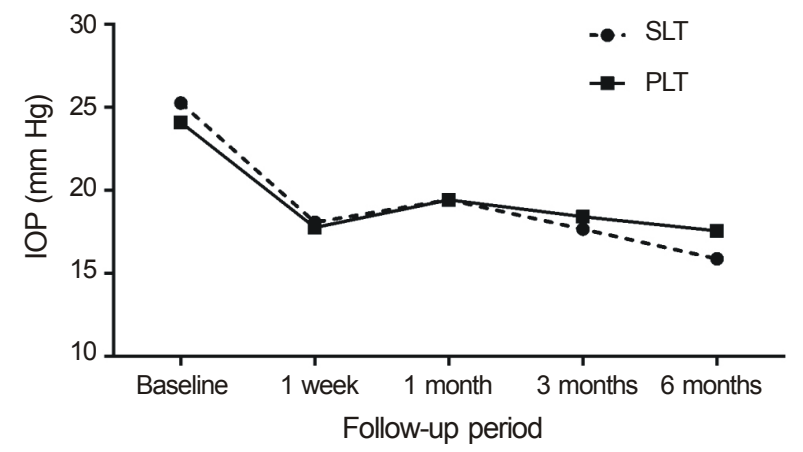

Figure 3. Changes in mean intraocular pressure after laser trabeculoplasty. No statistical differences between the groups during follow-up ( $p>0.05$, Mann-Whitney test). SLT = single spot laser trabeculoplasty; PLT = patterned laser trabeculoplasty.

술전에 비해 안압하강을 보였다. 패턴 레이저섬유주성형술 을 시행 받은 환자군의 술전 평균 안압은 $24.11 \pm 4.17$ $\mathrm{mmHg}$ 였으며, 1 주일 후 $17.78 \pm 2.49 \mathrm{mmHg}(26.3 \%$ 안압 감소), 1 개월 후 $19.44 \pm 5.15 \mathrm{mmHg}$ (19.4\% 안압감소), 3 개 월 후 $18.43 \pm 1.40 \mathrm{mmHg}$ (23.6\% 안압감소), 6 개월 후 $17.57 \pm 2.64 \mathrm{mmHg}(27.1 \%$ 안압감소)로 술전에 비해 안압 하강을 보였다(Table 2, Fig. 3). 단일 광응고반 레이저섬유 주성형술 및 패턴 레이저섬유주성형술 모두에서 시술 전 안압과 시술 후 1 주, 1 개월, 3 개월, 6 개월 후 안압은 통계학 적으로 유의한 차이가 있었다(Wilcoxon signed ranks test, $p<0.05)$.

시술 4 주 이후 측정한 안압이 술전 안압에 비하여 $20 \%$

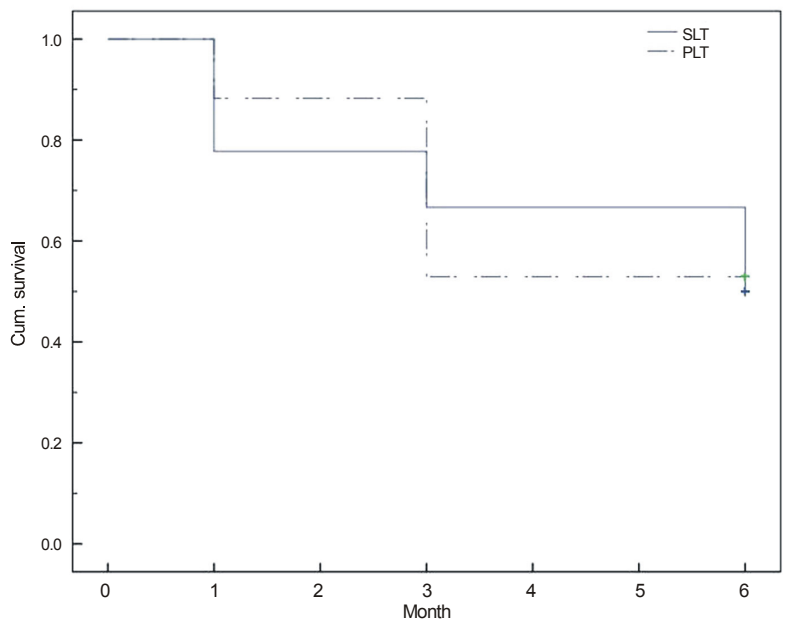

Figure 4. Kaplan-Meier survival curve using success definition in single spot laser trabeculoplasty and patterned laser trabeculoplasty groups. No statistical differences between the groups during follow-up $(p=0.93)$. Cum = cumulative; SLT $=$ single spot laser trabeculoplasty; PLT $=$ patterned laser trabeculoplasty.

미만으로 감소한 경우를 치료실패로 정의하여 두 군간의 치료 성공률 및 성공한 집단과 실패한 집단의 안압하강정 도를 비교하였다. 단일 광응고반 레이저섬유주성형술군에 서 6 개월 치료성공률은 $50 \%$, 패턴 레이저섬유주성형술에 서 6 개월 치료성공률은 $52.94 \%$ 로 두 군간의 유의한 차이가 없었다 $(p=0.87)$ (Table 3). 두 군에서 치료를 성공한 하위집 단은 치료를 실패한 하위집단에 비해 시술 전 안압이 유의 
하게 높았다(Table 4). 시술후 $1,3,6$ 개월에 치료실패 정의 에 의한 치료성공의 누적 생존율 비교에서 두 군간의 유의 한 차이는 없었다 $(p=0.93)$ (Fig. 4).

시술 후 합병증 검사를 위해 시술 1 시간 후 시행한 안압 검사에서 일시적인 안압상승은 발생하지 않았다. 1 주 후 세 극등현미경을 이용하여 전방염증 여부를 관찰하였으나 발 생하지 않았으며, 6 개월 후 주변홍채유착 여부를 관찰하였 으나 발생하지 않았다.

\section{고 찰}

아직까지 레이저섬유주성형술에 대한 작용기전은 명확 하지 않지만 몇 가지 가설이 존재한다. Wise ${ }^{6}$ 는 레이저 화 상에 의한 광응고로 인접한 조직의 수축이 발생하고 이에 따라 섬유주를 넓힐 것으로 생각하였다. Van Buskirk et $\mathrm{al}^{7}$ 은 레이저섬유주성형술이 세포분열을 촉진시켜 섬유주를 늘어나게하는 생물학적, 생화학적 기전을 제시하였다.

레이저섬유주성형술 후 IL-1B, TNF- $\alpha$ 와 같은 cytokine이 분비되어 matrix metalloproteinase를 변화시키고 방수유출 을 증가시키며 세포증식을 유발시키는 것이 확인되었으며, 이러한 생화학적 변화는 섬유주성형술 6-8주에 일어나는 것으로 보고되었다. ${ }^{8-10}$

개방각 녹내장 환자의 치료로 레이저섬유주성형술이 시 행되고 있는데 현재까지 아르곤레이저, 다이오드레이저, Micropulse 다이오드 레이저, Titanium-Sapphire 레이저, $\mathrm{Nd}: \mathrm{YAG}$ 레이저가 이용되고 있다. 각각의 레이저마다 성질 및 파장이 다르지만 섬유주의 변형을 일으켜 안압하강을 목표로 한다. ${ }^{10}$

아르곤레이저섬유주성형술은 488 또는 $514 \mathrm{~nm}$ 의 파장을 갖는 아르곤레이저를 이용한 치료로써 1973년 Worthen and Wickham ${ }^{11}$ 에 의해 처음으로 안압하강 효과가 보고되 었다. 1979년 Wise and Witter'는 18개월간 56안을 대상으 로 시행한 연구에서 아르곤레이저치료가 섬유주절제술과 비슷한 효과가 있음을 보고하였다. Park et $\mathrm{el}^{12}$ 은 개방각녹 내장 환자 35 안을 대상으로 아르곤레이저섬유주성형술을 시행하여 시술 1년 후 평균 $35.27 \%$ 의 안압하강을 보고하였 다. 하지만 아르곤레이저섬유주성형술은 비선택적으로 섬 유주에 광범위한 반흔형성 및 재치료 성공률이 낮은 단점 이 있다. 또한 포도막공막 유출로의 폐쇄, 각막내피세포의 증식을 유발하여 내피막의 형성을 일으켜 치료실패의 원인 이 될 수 있다.

다이오드 레이저섬유주성형술은 $810 \mathrm{~nm}$ 의 파장을 갖는 다이오드 레이저를 이용한 치료로써 아르곤레이저에 비해 조금 더 소형이며 고체상태로 휴대성의 장점이 있다. ${ }^{10}$ 아
르곤레이저섬유주성형술과 비교하여 유사한 결과 및 안정 성이 몇몇 연구에서 제시되었다. ${ }^{13,14}$

Micropulse 다이오드 레이저는 $810 \mathrm{~nm}$ 의 파장을 이용하 는데 매우 짧은 조사시간을 사용하여 열손상을 감소시키는 것을 목표로 사용되었다. Micropulse 다이오드 레이저섬유 주성형술은 레이저에 의해 유도되는 열에 의한 효과를 공 간적으로 제한하여 섬유주 세포에서 치사량이하의 광열효 과 및 치료효과를 이끌어낸다. 더욱더 짧은 조사시간을 이 용하기 때문에 연접한 조직으로 퍼지는 열이 감소하며, 또 한 pulse 사이에 냉각시간 연장의 효과가 있다. 이론상으로 각각의 micropulse는 응고적 괴사없이 세포의 온도를 상승 시킬 수 있다.

Titanium-Sapphire 레이저섬유주성형술은 $790 \mathrm{~nm}$ 파장의 레이저를 사용한다. 적외선 레이저파장을 갖는 TitaniumSapphire 레이저는 방수유출의 직접적인 영향을 갖고 있는 쉴렘관연접부로 좀더 깊숙히 침투할 수 있다. ${ }^{10}$

선택적레이저섬유주성형술은 $532 \mathrm{~nm}$ 의 Q-switched frequency-doubled Nd:YAG laser를 이용하여 섬유주 색소세 포만 선택적으로 파괴하는 방법이다. 선택적레이저섬유주절 제술을 시행 받은 환자에서 부검을 시행하여 섬유주의 응고적 손상 및 각공막, 포도막, 섬유주 기둥의 파괴과 관찰되지 않음 을 확인하였다. ${ }^{15}$ 아르곤레이저섬유주성형술과 달리 방수의 흐름을 방해하는 반흔형성이 적고 재시술이 가능하다는 장점 이 있다. 일반적으로 섬유주의 $180^{\circ}$ 영역에 "champagne bubbles"로 불리는 레이저 화상에서 약간의 공기방울이 보 일때까지 레이저 출력을 조절하여 겹지치 않게 광응고반을 총 50-70회 가량조사하는 것이 일반적인 프로토콜이다. ${ }^{16}$ Jang et $\mathrm{al}^{17}$ 은 180 도와 360 도 선택적레이저섬유주성형술을 시행하여 유사한 안압하강 효과를 보고하면서 합병증이 적 은 180 도 방식을 시행하는 것이 바람직하다고 하였다.

$10-20 \mathrm{~ms}$ 의 짧은 조사시간으로 열손상을 감소시키며 망막에 여러개의 광응고반을 만들수 있는 PASCAL Photocoagulator (OptiMedica Inc., Santa Clara, CA)가 2006년 소개되었으며 패 턴 레이저섬유주성형술로 불리는 computer-guided program 또한 포함되어 있어 망막질환뿐 아니라 개방각 녹내장환자 치료에도 사용되고 있다. 3 개의 줄로 22 개의 광응고반(총 66 개)의 패턴, 크기 $100 \mu \mathrm{m}$, 조사시간 $5 \mathrm{~ms}$ 로 한번에 $22.5^{\circ}$ 의 섬유주에 레이저를 조사하여 16 번의 조사로 $360^{\circ}$ 섬유 주에 레이저를 조사할 수 있다. $360^{\circ}$ 치료시 대략 $3.5 \mathrm{~J}$ 의 에너지로 1056 개의 광응고반, 섬유주면적의 $63 \%$ 에 해당하 는 영역 $8.3 \mathrm{~mm}^{2}$ 에 적용된다. 아르곤레이저섬유주성형술은 $100 \mathrm{~ms}$ 의 조사시간으로 $200 \mu \mathrm{m}$ 까지 열이 전달되는데 반해 패턴 레이저섬유주성형술은 $5 \mathrm{~ms}$ 의 조사시간을 사용하여 $50 \mu \mathrm{m}$ 까지 열이 전달되어 인접조직으로의 열에 의한 영향 
이 적다. ${ }^{4} \mathrm{Nd}: \mathrm{YAG}$ 레이저를 이용한 선택적레이저섬유주성 형술은 $3 \mathrm{~ns}$ 의 조사시간을 사용하여 열에 의한 영향이 가장 적은 장점을 갖는다. ${ }^{18}$

PASCAL Streamline $577^{\mathrm{TM}}$ 은 $577 \mathrm{~nm}$ 파장을 사용하는 PASCAL Photocoagulator로 $532 \mathrm{~nm}$ 파장에 비해 산란이 적고 망막색소상피에 정확하게 표적화되어 망막질환에 유 용하게 사용된다. Sramek et $\mathrm{al}^{19}$ 은 동물실험결과 $577 \mathrm{~nm}$ 레이저가 $532 \mathrm{~nm}$ 레이저에 비해 응고역치가 $26 \%$ 낮음을 보고하였다. 기존 PASCAL Photocoagulator에서의 패턴 레 이저섬유주성형술은 한 번에 66개의 광응고반이 섬유주의 $22.5^{\circ}$ 에 형성되는데 반해 PASCAL Streamline 577TM은 한 번에 39 개의 광응고반이 섬유주의 $12.25^{\circ}$ 에 형성되어 $360^{\circ}$ 섬유주성형술을 시행할 경우 평균 1248 개의 광응고반이 형 성된다. 패턴 레이저섬유주성형술은 39 개의 광응고반이 $200 \mathrm{~ms}$ 내에 조사되기 때문에 눈 움직임에 의한 영향을 최 소화할 수 있지만 곡률(curvature)을 적절히 조절해야 목표 로 하는 지점에 정확히 레이저를 조사할 수 있다. 단일 광 응고반 레이저섬유주성형술은 패턴 레이저섬유주성형술에 비해 광응고반 사이의 간격이 일정하지 않으며 술자의 숙 련도에 따라 차이가 발생할 수 있다. 현재까지 $577 \mathrm{~nm}$ 파 장을 이용한 레이저섬유주성형술을 시행한 연구는 보고되 지 않았다. 본 연구의 결과 $577 \mathrm{~nm}$ 파장을 사용하여도 안 압하강 효과가 있으며 패턴 레이저와 단일 광응고반 레이 저섬유주성형술 사이의 안압하강 효과 및 합병증 발생에 차이는 없었다. 하지만 대상 환자수가 적고 6 개월간의 짧은 경과관찰의 한계점이 있기 때문에 향후 많은 환자를 대상 으로 장기간의 연구가 진행되어야 할 것으로 생각된다.

\section{REFERENCES}

1) Wise JB, Witter SL. Argon laser therapy for open-angle glaucoma. A pilot study. Arch Ophthalmol 1979;97:319-22.

2) Latina MA, Park C. Selective targeting of trabecular meshwork cells: in vitro studies of pulsed and CW laser interactions. Exp Eye Res 1995;60:359-71.

3) Cho BJ, Kim TW, Woo SJ, et al. Short-term clinical outcome of patterned scanning laser photocoagulation with short exposure time in diabetic retinopathy. J Korean Ophthalmol Soc 2009;50:376-82.
4) Turati M, Gil-Carrasco F, Morales A, et al. Patterned laser trabeculoplasty. Ophthalmic Surg Lasers Imaging 2010;41:538-45.

5) Hodapp E, Parrish RK II, Anderson DR. Clinical decisions in glaucoma. St. Louis: Mosby, 1993:52-61.

6) Wise JB. Glaucoma treatment by trabecular tightening with the argon laser. Int Ophthalmol Clin 1981;21:69-78.

7) Van Buskirk EM, Pond V, Rosenquist RC, Acott TS. Argon laser trabeculoplasty. Studies of mechanism of action. Ophthalmology 1984;91:1005-10.

8) Alvarado JA, Alvarado RG, Yeh RF, et al. A new insight into the cellular regulation of aqueous outflow: how trabecular meshwork endothelial cells drive a mechanism that regulates the permeability of Schlemm's canal endothelial cells. Br J Ophthalmol 2005;89: 1500-5.

9) Bradley JM, Anderssohn AM, Colvis CM, et al. Mediation of laser trabeculoplasty-induced matrix metalloproteinase expression by IL-1beta and TNFalpha. Invest Ophthalmol Vis Sci 2000;41: 422-30.

10) Samples JR, Singh K, Lin SC, et al. Laser trabeculoplasty for open-angle glaucoma: a report by the american academy of ophthalmology. Ophthalmology 2011;118:2296-302.

11) Worthen DM, Wickham MG. Laser trabeculotomy in monkeys. Invest Ophthalmol 1973;12:707-11.

12) Park JJ, LEE JW, Lee KW. Comparison of clinical outcomes of argon laser versus selective laser trabeculoplasty in POAG. J Korean Ophthalmol Soc 2008;49:1491-500.

13) Brancato R, Carassa R, Trabucchi G. Diode laser compared with argon laser for trabeculoplasty. Am J Ophthalmol 1991;112:50-5.

14) Chung PY, Schuman JS, Netland PA, et al. Five-year results of a randomized, prospective, clinical trial of diode vs argon laser trabeculoplasty for open-angle glaucoma. Am J Ophthalmol 1998;126: 185-90.

15) Kramer TR, Noecker RJ. Comparison of the morphologic changes after selective laser trabeculoplasty and argon laser trabeculoplasty in human eye bank eyes. Ophthalmology 2001;108:773-9.

16) Allingham RR. Shields textbook of glaucoma, 6th ed. Wolters Kluwer: Lippincott Williams\&Wlikins, 2011;455.

17) Jang YS, Kim JM, Lim TH, et al. Comparison of $180^{\circ}$ and $360^{\circ}$ selective laser trabeculoplasty. J Korean Ophthalmol Soc 2012; 53:291-6

18) Schuele G, Rumohr M, Huettmann G, Brinkmann R. RPE damage thresholds and mechanisms for laser exposure in the microsecond-to-milisecond time regimen. Invest Ophthalmol Vis Sci 2005;46:714-9.

19) Sramek CK, Leung LS, Paulus YM, Palanker DV. Therapeutic window of retinal photocoagulation with green (532-nm) and yellow (577-nm) lasers. Ophthalmic Surg Lasers Imaging 2012;43:341-7. 


\section{= 국문초록 $=$}

\section{$577 \mathrm{~nm}$ 레이저 섬유주성형술의 단기 임상효과}

목적: $577 \mathrm{~nm}$ 레이저를 이용한 단일 광응고반 레이저섬유주성형술과 패턴 레이저섬유주성형술의 안압 하강효과를 알아보고자 하였다. 대상과 방법: 원발개방각녹내장 환자 35 명을 대상으로 18 안은 $360^{\circ}$ 단일 광응고반 레이저섬유주성형술을 시행하였고, 17 안은 $360^{\circ}$ 패턴 레이저섬유주성형술을 시행하여 시술 후1주, 1 개월, 3 개월, 6 개월의 안압검사 및 세극등 현미경검사를 시행하였다.

결과: 단일 광응고반 레이저섬유주성형술을 시행한 군에서 술전 안압은 평균 $25.27 \pm 7.51 \mathrm{mmHg}$ 였고, 술후 6 개월째 안압은 평균 $15.89 \pm 3.89 \mathrm{mmHg}$ 로 술전에 비해 평균 $37.1 \%$ 안압하강 효과가 있었다. 패턴 레이저 섬유주성형술을 시행한 군에서 술전 안압은 평균 $24.11 \pm 4.17 \mathrm{mmHg}$ 였고, 술후 6 개월째 안압은 평균 $17.57 \pm 2.64 \mathrm{mmHg}$ 로 술전에 비해 평균 $27.1 \%$ 안압하강 효과가 있었다. 결론: Optically pumped semiconductor laser $(577 \mathrm{~nm})$ 를 이용한 단일 광응고반 레이저섬유주성형술과 패턴 레이저섬유주성형술은 안압하강 효과가 있으며, 시술방법에 따른 안압하강의 효과는 두 군간에 통계학적으로 유의한 차이는 없었다 $(p=0.40)$. 〈대한안과학회지 2014;55(4):563-569〉 